\title{
VERTICAL HEAT FLUX ANALYSES OVER PASTURE AND FOREST IN AMAZÔNIA USING A LES MODEL
}

\author{
Theomar T. de A. T. Neves ${ }^{1}$, Gilberto Fisch², \\ Sigfried Raasch ${ }^{3}$ \\ ${ }^{1} \mathrm{INPE},{ }^{2} \mathrm{CTA},{ }^{3} \mathrm{IMUK}$ \\ ${ }^{1}$ theomar.neves@cptec.inpe.br
}

\begin{abstract}
As análises de fluxo de calor vertical foram feitas sobre um sítio de pastagem e floresta da Amazônia, usando um dia durante a estação seca (RBLE 3). Depois de uma validação satisfatória, as simulações apresentaram para a pastagem um rápido e mais alto desenvolvimento convectivo, devido ao alto fluxo de calor sensível na superfície e um baixo decaimento, no topo da camada, no final do dia.
\end{abstract}

\section{INTRODUCTION}

The analysis of heat and moisture fluxes is an important result to better understand the processes of convection, especially in a region strongly influenced by convective systems like Amazonia (Molion, 1987). With the computational improvements and modeling implementations, the development of new methods as the LES (Large Eddy Simulation), which combinations of processes by reducing the computational cost and analysis more defined of smaller scales phenomena are possible. The model PALM (PArallelized Les Model), LES model used in this work, has been widely applied to study different flow regimes in the heterogeneous heated Convective Boundary Layer (e.g. Steinfeld et al., 2008; Maronga and Raasch, 2012). Thus, this work aim through LES simulations analyse the vertical heat flux over a pasture and forest site.

\section{METHODS}

The simulations were carried out using cyclic lateral boundaries, and MOST (MoninObukhov similarity theory) applied between the surface and the first computational grid level. 
At the beginning of each simulation, a random generator is used to create small perturbations of the velocity field to initiate the turbulence.

The simulations presented were for the day Aug 15, 1994. starting at 8 Local Time, when the turbulent fluxes become positive, having vertical profiles of potential temperature $(\theta)$, specific humidity (q) and wind components ( $u$ and v), together with surface sensible and latent heat fluxes as input data. Such data was obtained during the experiment RBLE3 (Rondônia Boundary Layer Experiment), which is fully described (data and sites characteristics) in Fisch et al. (2004).

\section{RESULTS AND DISCUSSION}
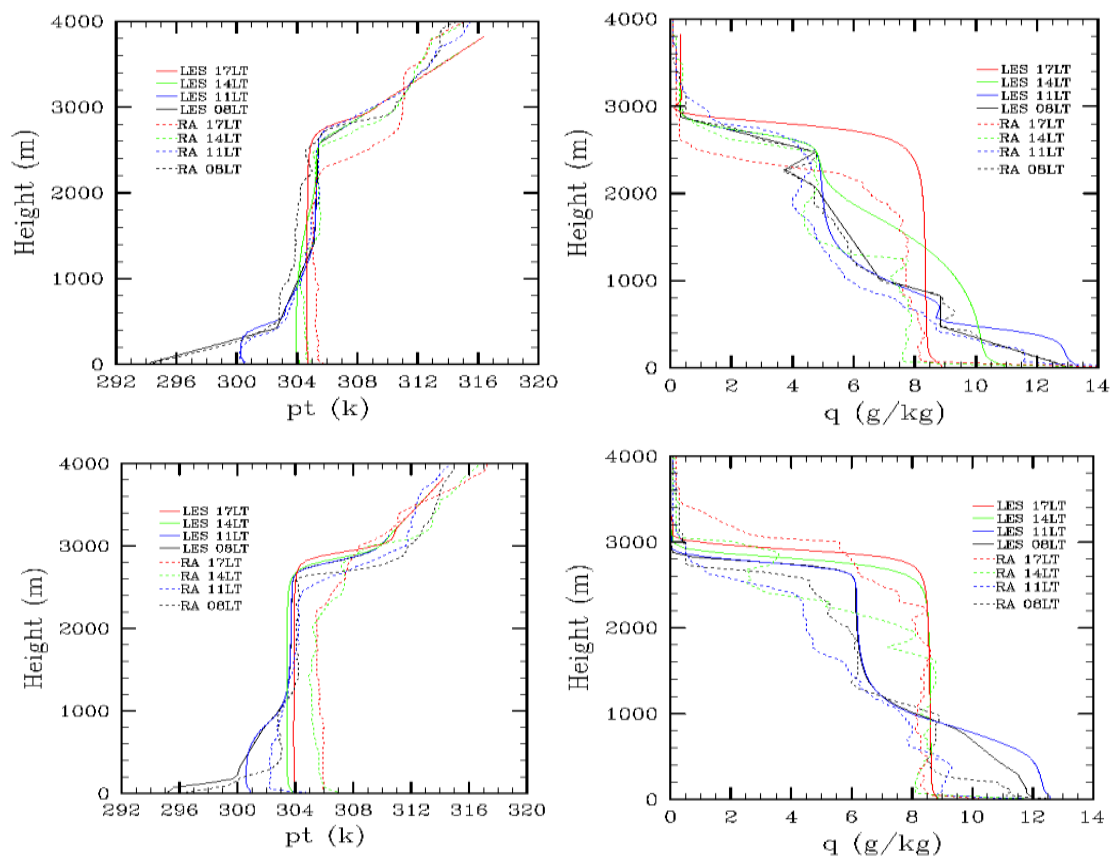

Figure 1: Profiles of potential temperature (left) and specific humidity (right) for forest (top) and pasture (bottom) sites during the day.

Initially, it was performed a validation (Figure 1), using the radiosondes launched throughout the day against the simulations profiles, which are domain- and time-averaged of 10-min mean. These results showed that the simulations performed very well. The forest site was better represented, since the pasture, due to its heterogeneity (e.g. savannas and cropplants), presented a horizontal advection that caused a difference of potential temperature in the mixed layer at $14 \mathrm{LT}$ and $17 \mathrm{LT}$, with about $2.0 \mathrm{~K}$. For the specific humidity over the pasture was better represented showing some large scales effects also in the forest. 
The computed surface sensible heat flux in pasture $\left(190.0 \mathrm{~W} . \mathrm{m}^{-2}\right)$ had a difference of +50.0 $\mathrm{W} . \mathrm{m}^{-2}$ in comparison to the forest and it is responsible to produce a stronger mixture in the atmosphere. In Figure 2, the simulation of vertical sensible heat flux has a peaked (-111.3 $\mathrm{W} . \mathrm{m}^{-2}$ ) in $1400 \mathrm{~m}$ height at around $14 \mathrm{LT}$ over the forest and this strong mixing lasts until 16 LT, while in the pasture the mixture was almost completely established at 14 LT. Also, it has the maximum negative energy $\left(-87.0 \mathrm{~W} \cdot \mathrm{m}^{-2}\right)$ one hour early in $2000 \mathrm{~m}$ height.

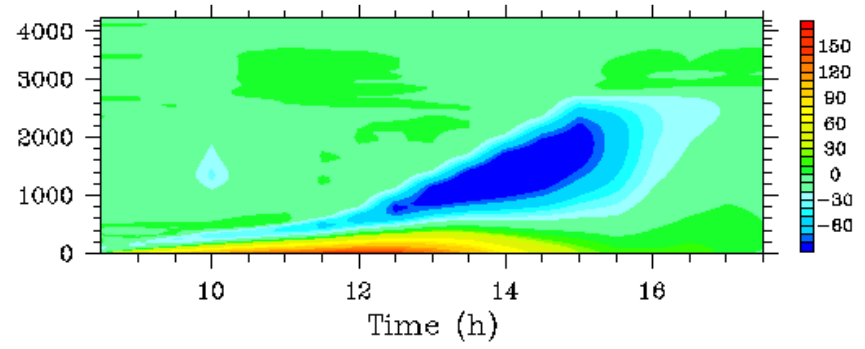

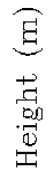

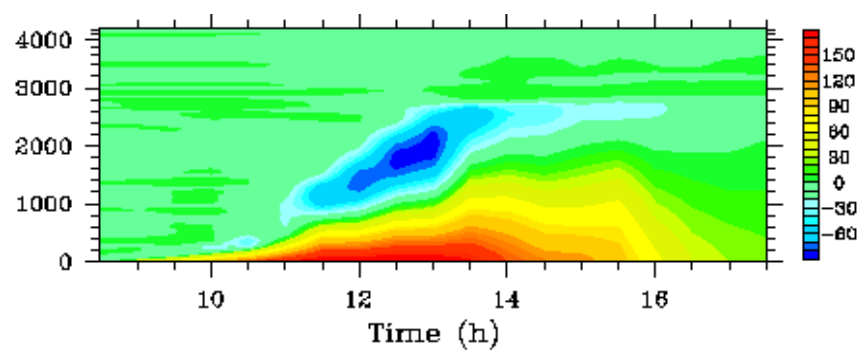

Figure 2: Heat fluxes simulated over the forest (top) and pasture (bottom).

Analyzing the daytime evolution by profiles, over the forest, the mixing layer depth, that is the height of the minimum heat flux, grows slow and gradual. After the peak, at 14 LT, the flux has a fast decay, principally from 15 to $16 \mathrm{LT}$ with reduce of $60.0 \mathrm{~W} . \mathrm{m}^{-2}$. On the other hand, the pasture, had a fast increase of energy until $13 \mathrm{LT}$, reaching $-57.0 \mathrm{~W} . \mathrm{m}^{-2}$ (12 LT), and a slow decay from $14 \mathrm{LT}$ (mean $11.4 \mathrm{~W} \cdot \mathrm{m}^{-2} \cdot \mathrm{h}^{-1}$ ).
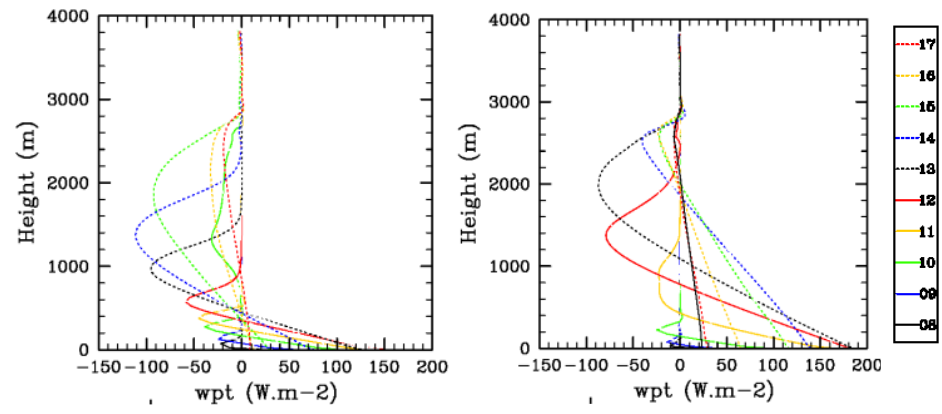

Figure 3: Daytime simulated heat fluxes profiles evolution over the forest (left) and pasture (right). 


\section{CONCLUSIONS}

In summary, with the most intense release of sensible heat flux over the pasture site, a faster convective development occur and, in the atmosphere, it has a slow decay of energy after the peak, what increase even more the mixing depth. In spite of the forest has a better atmospheric heat flux contribution, since it has a higher humidity in surface, the convection grows slower, because of the net radiation conversion be more favorable to latent heat flux.

\section{ACKNOWLEDGMENTS}

The authors thanks for the support of CAPES and CNPq during the PhD support for the main author and during his external research by the CsF (241757/2012-6).

\section{REFERENCES}

Molion, L. C. B.. Climatologia Dinâmica da região Amazônica: mecanismos de precipitação. Rev Bras Meteorol, v. 2, n. 1, p. 107-117, 1987.

Steinfeld, G., Raasch S., Markkanen T.. Footprints in homogeneously and heterogeneously driven boundary layers derived from a Lagrangian stochastic particle model embedded into large-eddy simulation. Bound-Layer Meteorol, n 129, p. 225-248, 2008.

Björn, M., Raasch, S.. Large-eddy simulations of surface heterogeneity effects on the convective boundary layer during the LITFASS-2003 Experiment. Bound.-Layer Meteor. 2012, DOI: 10.1007/s10546-012-9748-z. 